\title{
Social-benefit certification as a game
}

\author{
Ralf Buckley \\ International Centre for Ecotourism Research, Griffith University, Qld 4222, Australia
}

\begin{abstract}
Tourism ecocertification programs persist and proliferate despite low market penetration and apparent consumer indifference. This has been viewed simply as an early-adoption phase. A two-decade historical analysis of development patterns for 17 programs, however, suggests that they can be analysed as a multi-move political game between corporate and civic advocates, where neither can quit without losing. The political-game framework yields predictions which are testably different from a pure-market early-adopter framework. It also draws a key distinction between consumer-benefit and social-benefit measures, applicable to corporate social responsibility initiatives in many industry sectors.
\end{abstract}

Keywords: Market, Regulation, Ecolabel, Game, Theory, Consumer, Environment, Responsibility, Sustainable, Tourism

\section{Introduction}

Tourism ecocertification programs originated over 25 years ago, and have proliferated for over two decades (Black \& Crabtree, 2007; Dredge \& Jamal, 2011; Font, 2002; Font \& Buckley, 2001;Herremans, Pyasi, \& Lu, 2011; Honey, 2002; Treves \& Jones, 2010). Despite some turnover (Buckley, 2001), most programs remain operational, and new programs are still being created (Baddeley \& Font, 2011; Mbaiwa, Magole, \& Kgathi, 2011). This occurs even though market penetration remains low and individual tourists remain largely uninterested (Buckley, 2012; McKenna, Williams, \& Cooper, 2011; Mair \& Jago, 2010; Mason, 2007; Miller, Rathouse, Scarles, Holmes, \& Tribe, 2010; Rivera, 2002; Rowe \& Higham, 2007). There are parallels for ecocertification more broadly (Belton, Murray, Young, Telfer, \& Little, 2010; Edwards, Fisher, \& Wilcove, 2011; Whiteman, 2011). This contribution examines why.

Many commercial products, in all industry sectors, possess characteristics valued by consumers but indiscernible at point of purchase. These are divisible into experience features, revealed during consumption; and credence features, taken on trust (Bonroy \& Constantatos, 
2008; Mason, 2006; 2011). Social mechanisms to provide quality assurance for such products include: statutory systems, such as regulated standards and consumer protection law; twoparty systems, such as contracts and guarantees; and various forms of third-party certification. Certification programs may be classified broadly into two categories, referred to here as consumer-benefit and social-benefit. Consumer-benefit programs certify features which benefit the consumer individually: e.g., restaurant quality ratings. Their reliability and market penetration may be maintained purely by consumer purchase pressure, a market mechanism. Social-benefit schemes certify features which contribute to broader social goals, such as poverty alleviation, public health or pollution control, and many are tied to regulatory standards. They influence only those consumers prepared to pay individual premiums for shared returns; and represent one form of corporate social responsibility, CSR. This distinction is applicable in all industry sectors.

In tourism (Table 1), guide skills and destination quality are experience goods, and relevant ecocertificates benefit consumers directly (Black, 2007; Blue Flag, 2012; McKenna et al., 2011; Zhong, Deng, Song, \& Ding, 2011). Environmental management performance (EMP), however, is generally a credence feature with social benefit ecocertification. Most such programs are not transparent to consumers and have low market penetration, weak criteria, little audit and few sanctions (Buckley, 2002, 2012; Goodstein, 2007; Mason, 2007; Parsons \& Grant, 2007). Small-scale tours in protected areas provide one exception. For these, EMP is perceptible to the parks agency, though not to the tourist. Therefore, EMP is an experience good for the agency, though a credence good for the tourist. Agencies grant preferential permitting opportunities to ecocertified operators, providing a direct market advantage (Ingram, 2007; Rowe \& Higham, 2007). This mechanism, however, applies only to that subsector.

By far the majority of tourism ecocertification programs apply to EMP in large-scale mainstream tourism accommodation, transport and activities, and these are the focus of the current analysis. Aggregate worldwide market penetration of such programs, i.e. the total number of ecocertified enterprises divided by the total number of eligible enterprises, is $<0.1 \%$. The orthodox view is that this represents an early adoption phase. Under this view, purchasing ecocertified tourism products provides satisfaction to individual consumers who care about EMP and rely on ecocertificates; and tourism providers improve yield by using 
ecocertificates in selective marketing to such consumers. Tourism enterprises may also cut operating costs through improved EMP, but ecocertification itself does not affect this.

This view considers ecocertification as a form of CSR, which may boost profits through improved interactions with customers, staff, suppliers, shareholders, competitors or government (Aguilera, Rupp, Williams, \& Ganapathi, 2007; Basu \& Palazzo, 2008; Bohdanowicz \& Zientara, 2008; Campbell, 2007; Crane, McWilliams, Matten, Moon, \& Siegel, 2008; Denicolo, 2008; Fisher-Vanden \& Thorburn, 2011; Fleckinger \& Glachant, 2011; Fuerst \& McAllister, 2011; Hahn, Fley, Florian, Spresny, \& Fischer, 2007; Khanna, 2001; Khanna \& Kumar, 2011; Lee, Hsu, Han, \& Kim, 2010; Lyon \& Maxwell, 2008; Nunez, 2007; Ott, Choi, Cardie, \& Hancock, 2011; Ottman, Stafford, \& Hartman, 2006; Sacconi, 2006; Tang, Hu, \& Smith, 2008; Van't Veld \& Kotchen, 2011; Wagner, 2011; Whittaker, 2011).

Evidence from the tourism sector is mixed. Individual hotel chains cite various reasons for adopting either environmental management practices or ecocertification programs (Chan \&Wong, 2006; El Dief \& Font, 2012; Enz \& Siguaw, 1999; Goodman, 2000). Hotels, restaurants, airlines and casinos with better EMP sometimes show higher economic performance, but sometimes not (Álvarez, Burgos, \& Céspedes, 2001; Carmona-Moreno, Cespedes-Lorente, \& de Burgos-Jimenez, 2004; Claver-Cortes, Molina-Azoin, PereiraMoliner, \& Lopez-Gamero, 2007; Cowper-Smith \& de Grosbois, 2011; De Grosbois \& Fennell, 2011; Inoue \& Lee, 2011; Kassinis \& Soteriou, 2003; Nicolau, 2008; Sheldon \& Park, 2011); and economic performance reflects actual EMP, not ecocertification, which is poorly correlated (Bonilla-Priego, Najera, \& Font, 2011; Rivera, 2002). Overall, therefore, it is unconvincing that after 25 years, EMP ecocertification in mainstream tourism is still sparse and unreliable solely because it is new.

This contribution derives an alternative analytical framework, from analysis of actual historical development patterns in tourism ecocertification programs. The framework is formulated as an evolving multi-move two-team political game, between corporate and civic advocates respectively, where neither can quit without losing. This political-game framework yields testably different predictions from the pure-market early-adopter framework. 
In theoretical terms, a game is an interaction between two or more players with independent goals, where each player decides their own strategy partly by attempting to predict the strategies of other players. The most concise definition of a game is simply 'an interactive decision problem' (McCain, 2009, 2010, p. 625). In some games, all players can achieve their goals; in some, only one can win; and in some, all can lose. Many real-life interactions between individuals and organizations can be analysed as games.

In games with the same formal structure, the same strategies yield the same outcomes, even if the real-life representations of these structures are completely different. Game theory thus provides a technique to transfer experience and analysis from one situation to another.

There are many different types and typologies of games (McCain, 2009, 2010, p. 625). All can be analysed in terms of three basic components, namely players, strategies and payoffs (Cachon \& Netessine, 2004; Yang, Huang, Song, \& Liang, 2009). The players may be: individual people; groups or organizations; or mechanical devices or stochastic events. Games can be played at all time scales, from instantaneous to evolutionary. Games can have two players, or several, or an indefinite number, either in single or multiple tiers. The moves may be few or many, predefined or open-ended, simple or complex, repeated or once-off, fixed or indefinite in number.

In some games, the first player has an advantage; in others, the second or later players. The rules may be determined in advance for the entire game, or the players may be able to change some of the rules as part of the play, as in the America's Cup yacht race or the imaginary game of Calvinball (Watterton, 1996; pp. 100-103). Many games involve the development of strategies which include communication signals, either accurate or deceptive. Some games can be analysed completely, so that every possible series of moves, and the consequent outcomes, can be identified; others can be analysed only partially.

Game theory is not yet widely used in tourism research (Stabler, Papatheodorou, \& Sinclair, 2010, p. 506; Yang et al., 2009). Early mentions include Brown (1996), Reed (1997) and Huybers and Bennett (2003). Applications include: hotel pricing (Chung, 2000); marketing agreements (Bastakis, Buhalis, \& Butler, 2004); investment (Candela \& Cellini, 2006; Wie, 2005); service quality (Garcia \& Tugores, 2006); over-use of nature (Bimonte, 2008); theme parks (Yang et al., 2009); above-compliance EMP (Blanco, Rey-Maquieira, \& Lozano, 2009; 
Blanco, Lozano, \& Rey-Maquieira, 2009); and stakeholder cooperation in the Alps (Beritelli, 2011). None of these examined ecocertification.

\section{Tourism ecocertification as an evolutionary political game}

Data were derived from a comparative historical analysis of development processes in 17 individual tourism ecocertification programmes (Table 2). Many such programs are well documented (Black \& Crabtree, 2007; Bricker \& Schultz, 2011; Font \& Buckley, 2001; Font, Haas, Thorpe, \& Forsyth, 2001; Honey, 2002). Those used here are selected because of direct involvement, through: invitations to comment on early drafts; participation in planning meetings and public debates; provision of publications and advice on request; and evaluations on behalf of third-party agencies. These were open processes, but involvement was by invitation and/or interest, and outcomes had limited distribution. Only programmes operating at global, continental or subcontinental scales are covered by this analysis. Small programmes operating only at very local scales, eg for single villages in the European Alps (Font et al., 2001) have not been included. Each of the individual programmes in Table 2 followed its own particular development path; but in aggregate, they can be summarised as in Fig. 1.

The framework in Fig. 1 allocates all stakeholders into two teams, referred to as corporate advocates and civic advocates. Corporate advocates include tourism industry operators, tourism

industry associations, government tourism portfolios, destination marketing organisations (DMOs) at all scales, and industry-based award, label and certification providers. Civic advocates include environmental non-government organisations (ENGOs), government parks and environment agencies, and ENGO-operated ecolabel schemes. That is, the players in Fig. 1 are not individual firms or NGOs, but notional aggregate interests. Fig. 1 shows a series of game plays under which the corporate advocates made a move, shown in the left-hand column of each row; the civic advocates made a counter-move, shown in the right-hand column of the same row; the corporate advocates responded with a new (counter-counter) move, shown in the next row; and so on. Where the civic advocates started a new play, this is shown in the right-hand column, with a blank cell in the lefthand column.

The main game is shown as a single series of sequential moves, which is an analytical simplification. In reality, different sections of this game were played out in parallel for different ecocertification schemes in different places, with different speeds and starting dates. 
In addition, the members of each of the two teams are shown as acting in unity and simultaneously, so that each team can be represented as a single player. In reality, there were many side and subsidiary games within each team. The two main examples of these are also included in Fig. 1. One of these is the struggle between different ecocertification schemes, with a period when one particular program attempted unsuccessfully to gain global control. The other is the side game associated with definitions, use, and certification of the term ecotourism, separately from broader ecocertification programs applicable throughout the mainstream tourism industry.

Fig. 1 also summarises points at which, under immature-market models of third-party certification, retail tourists might have been expected to respond. The historical evidence is that they did not. The game is between corporate and civic advocates, not consumers. Fig. 1 indicates that for at least 3 plays, shown as '***', civic advocates have not produced any effective counter-move. Corporate advocates are still constructing new forms of ecocertificate, sustainability report, responsibility award, conservation label and so on, with no real social or environmental quality assurance (Buckley, 2012). The civic advocates' attempts at global accreditation were co-opted into the GSTC, which are so vague as to be almost completely ineffective, and bought the corporate advocates over a decade in additional wriggle room.

Figs. 2 and 3 show how the historical events summarised in Fig. 1 can be simplified into a repeated-move two-player game. In Fig. 2, all the historical moves by corporate advocates are treated as claims of high EMP, and moves by civic advocates as attempts to debunk such claims. This shows that the game ends if either player leaves or fails, but continues indefinitely if both keep playing. This is summarised in Fig. 3, which shows the payoffs in each case. The costs for each player to keep making each move are not known quantitatively, but they are much less (shown as _ $(<<1)$ ) than those of quitting the game and letting the other player score a definitive win (shown as _1). Note that individual firms and NGOs can, and do, leave and join the corporate and civic teams respectively, as long as the teams keep playing. Note also that membership of the corporate team is not the same as membership of a tourism ecocertification program. It is the program providers and other industry bodies, not the individual ecocertified enterprises, which make up the team. 
The apparently paradoxical proliferation, persistence and low penetration of EMP ecocertification programs in mainstream tourism, even though they are largely ignored by individual tourists, is thus comprehensible if the historical events outlined in Fig. 1 are perceived as part of a strategic policy game. The game involves a set of political manoeuvres, whereby civic advocates attempt to impose improved environmental management measures in tourism, and corporate advocates attempt to escape any such measures, which they see as involving restrictions and costs. This formulation, if it continues with no external intervention, no change in structure, and no new moves, indicates that the game will continue indefinitely and that neither team will ever achieve a definitive win unless the other team stops playing.

\section{Conclusions}

For EMP ecocertification in mainstream tourism, the politicalgame framework yields different predictions from the immature-market framework (Table 3). The immature-market framework predicts that tourism ecocertification providers should behave like businesses in any sector, with large certification providers outcompeting smaller ones, and operating across subsectors and countries to provide information to tourists everywhere. Several schemes have tried this but failed, even with public funds from the UN, World Bank, European Union or Australian Government. This framework also predicts that information provided by tourism ecocertification programmes should become successively more complete, accurate, detailed, relevant and transparent to the final purchasers and consumers of tourism products, through competition between programs. There is no evidence of this (Buckley, 2012).

The political-game framework predicts that EMP ecocertification programs will proliferate but remain small, with different countries developing their own programs; and that the quality of information will remain poor. It predicts a continuing and unresolved series of competing claims and counterclaims by corporate and civic advocates respectively: i.e., a continuation of the status quo. These tests can be applied over forthcoming years. Both the political-game framework to CSR and the distinction between consumer-benefit and social-benefit certification programmes, are also applicable across all industry sectors, not only tourism.

If the immature-market framework were correct, we could anticipate that programs for EMP ecocertification in tourism would gradually become more useful to consumers, enterprises and regulators alike, evolving greater accuracy, relevance and transparency. This does not 
seem to have happened to date. The political-game framework proposed here, in contrast, indicates that industry-led EMP ecocertification programs in tourism will never become sufficiently reliable to be useful to consumers or regulators. They are useful only to corporate advocates, not to civic advocates or consumers. Under this framework, we can expect that only consumer-benefit certification programs will evolve towards greater reliability through internal pressures alone. Social-benefit programs do not become reliable unless they are translated into enforceable government standards and regulations. That is the only mechanism by which the civic advocates can win this particular political game. 


\section{References}

Aguilera, R. V., Rupp, D. E., Williams, C. A., \& Ganapathi, J. (2007). Putting the S back in corporate social responsibility: a multilevel theory of social change in organisations. Academy of Management Review, 32(3), 836-863.

Álvarez, G. M. J., Burgos, J. J., \& Céspedes, L. J. J. (2001). An analysis of environmental management, organisational context and performance of Spanish hotels. Omega, 29, 457-471.

Baddeley, J., \& Font, X. (2011). Barriers to tour operator sustainable supply chain management. Tourism Recreation Research, 36(3), 205-214.

Bastakis, C., Buhalis, D., \& Butler, R. (2004). The perception of small and medium sized tourism accommodation providers on the impacts of the tour operators' power in the Eastern Mediterranean. Tourism Management, 25, 151-170.

Basu, K., \& Palazzo, G. (2008). Corporate social responsibility: a process model of sensemaking. The Academy of Management Review, 33(1), 122-136.

Belton, B., Murray, F., Young, J., Telfer, T., \& Little, D. C. (2010). Passing the panda standard: a TAD off the mark? Ambio, 39, 2-13.

Beritelli, P. (2011). Cooperation among prominent actors in a tourist destination. Annals of Tourism Research, 38, 607-629.

Bimonte, S. (2008). The 'tragedy of tourism resources' as the outcome of a strategic game: a new analytical framework. Ecological Economics, 67(3), 457-464.

Black, R. (2007). Professional certification: a mechanism to enhance ecotour guide performance. In R. Black, \& A. Crabtree (Eds.), Quality assurance and certification in ecotourism (pp. 316-336). Wallingford: CAB International.

Black, R., \& Crabtree, A. (2007). Quality assurance and certification in ecotourism. Wallingford: $\mathrm{CAB}$ International. 
Blanco, E., Lozano, J., \& Rey-Maquieira, J. (2009). A dynamic approach to voluntary environmental contributions in tourism. Ecological Economics, 69(1), 104-114.

http://dx.doi.org/10.1016/j.ecolecon.2009.07.012.

Blanco, E., Rey-Maquieira, J., \& Lozano, J. (2009). Economic incentives for tourism firms to undertake voluntary environmental management. Tourism Management, 30, 112-122.

Blue Flag. (2012). Accessed 05.01.12. http://www.blueflag.org/.

Bohdanowicz, P., \& Zientara, P. (2008). Corporate social responsibility in hospitality: issues and implications. A case study of Scandic. Scandinavian Journal of Hospitality and Tourism, $8(4), 271-293$.

Bonilla-Priego, M. J., Najera, J. J., \& Font, X. (2011). Environmental management decisionmaking in certified hotels. Journal of Sustainable Tourism, 19(3), 361-381.

Bonroy, O., \& Constantatos, C. (2008). On the use of labels in credence goods markets. Journal of Regulatory Economics, 33(3), 237-252.

Bricker, K. S., \& Schultz, J. (2011). Sustainable tourism in the USA: a comparative look at the global sustainable tourism criteria. Tourism Recreation Research, 36(3), 215e229.

Brown, M. (1996). Environmental policy in the hotel sector: 'green' strategy or stratagem? International Journal of Contemporary Hospitality Management, 8(3), 18-23.

Buckley, R. C. (2001). Turnover and trends in tourism ecolabel schemes. In X. Font, \& R. C. Buckley (Eds.), Tourism ecolabelling (pp. 189-212). Wallingford: CAB International.

Buckley, R. C. (2002). Tourism ecolabels. Annals of Tourism Research, 29, 183-208.

Buckley, R. C. (2012). Sustainability reporting and ecocertification in tourism. Tourism Recreation Research, 37(1), 85-90. 
Cachon, G. P., \& Netessine, S. (2004). Game theoretic application in supply chain analysis. In D. Simchi-Levi, S. David Wu, \& Z.-J. (Max) Shen (Eds.). Handbook of quantitative supply chain analysis: Modeling in the e-business era, Vol. 2. Norwell, MA: Kluwer Academic Publishers.

Campbell, J. L. (2007). Why would corporations behave in socially responsible ways? An institutional theory of corporate social responsibility. Academy of Management Review, 32(3), 946-967.

Candela, G., \& Cellini, R. (2006). Investment in tourism market: a dynamic model of differentiated oligopoly. Environmental and Resource Economics, 35, 41-58.

Carmona-Moreno, E., Cespedes-Lorente, J., \& de Burgos-Jimenez, J. (2004). Environmental strategies in Spanish hotels: contextual factors and performance. The Service Industries Journal, 24(3), 101-130.

Chan, E. S. W., \& Wong, S. C. K. (2006). Motivations for ISO 14001 in the hotel industry. Tourism Management, 27, 481-492.

Chung, K. Y. (2000). Hotel room rate pricing strategy for market share in oligopolistic competition - eight-year longitudinal study of super deluxe hotels in Seoul. Tourism Management, 21, 135-145.

Claver-Cortes, E., Molina-Azoin, J., Pereira-Moliner, J., \& Lopez-Gamero, M. D. (2007). Environmental strategies and their impact on hotel performance. Journal of Sustainable Tourism, 15(6), 663-679.

Cowper-Smith, A., \& de Grosbois, D. (2011). The adoption of corporate social responsibility practices in the airline industry. Journal of Sustainable Tourism, 19, 59-77.

Crane, A., McWilliams, A., Matten, D., Moon, J., \& Siegel, D. S. (2008). The Oxford handbook of corporate social responsibility. Oxford: Oxford University Press. 
De Grosbois, D., \& Fennel1, D. (2011). Carbon footprint of the global hotel companies: comparison of methodologies and results. Tourism Recreation Research, 6(3), 231-245.

Denicolo, V. (2008). A signaling model of environmental overcompliance. Journal of Economic Behaviour and Organization, 68(1), 293-303.

Dredge, D., \& Jamal, T. (2011). Certification and indicators. Tourism Recreation Research, 36, 203-204.

Edwards, D. P., Fisher, B., \& Wilcove, D. S. (2011). Green labelling being misused. Nature, $475,174$.

El Dief, M., \& Font, X. (2012). Determinants of environmental management in the Red Sea Hotels: personal and organizational values and contextual variables. Journal of Hospitality and Tourism Research, 36(1), 115-137.

Enz, C. A., \& Siguaw, J. A. (1999). Best hotel environmental practices. Cornell Hotel and Restaurant Administration Quarterly, 40(5), 72-77.

Field Guides Association of South Africa. (2012). Welcome to FGASA. Accessed 26.06.12. www.fgasa.co.za.

Fisher-Vanden, K., \& Thorburn, K. S. (2011). Voluntary corporate environmental initiatives and shareholder wealth. Journal of Environmental Economics and Management, 62, 430-445.

Fleckinger, P., \& Glachant, M. (2011). Negotiating a voluntary agreement when firms selfregulate. Journal of Environmental Economics and Management, 62, 41-52.

Font, X. (2002). Environmental certification in tourism and hospitality: progress, process and prospects. Tourism Management, 23(3), 197-205.

Font, X., \& Buckley, R. C. (2001). Tourism ecolabelling. Wallingford: CAB International. 
Font, X., Haas, E., Thorpe, K., \& Forsyth, L. (2001). Directory of tourism ecolabels. In X. Font, \& R. C. Buckley (Eds.), Tourism ecolabelling (pp. 271-348). Wallingford: CAB International.

Fuerst, F., \& McAllister, P. (2011). Eco-labelling in commercial office markets: do LEED and Energy Star offices obtain multiple premiums? Ecological Economics, 70, 1220-1230.

Garcia, D., \& Tugores, M. (2006). Optimal choice of quality in hotel services. Annals of Tourism Research, 33, 456-469.

GBRMPA. (2012). Great Barrier Reef marine Park Authority. Working together today for a healthier Reef tomorrow. Outlook for the Reef, high standard tourism programme. Accessed 06.01.12. http://www.gbrmpa.gov.au/.

Goodman, A. (2000). Implementing sustainability in service operations at Scandic hotels. Interfaces, 30(3), 202-214.

Goodstein, C. (2007). Smart voyager: protecting the Galapagos Islands. In R. Black, \& A. Crabtree (Eds.), Quality assurance and certification in ecotourism (pp. 65-80). Wallingford: CAB International.

Hahn, C., Fley, B., Florian, M., Spresny, D., \& Fischer, K. (2007). Social reputation: a mechanism for flexible self-regulation of multiagent systems. Journal of Artificial Societies and Social Simulation, 10(2), 1e2.

Herremans, I., Pyasi, N., \& Lu, J. (2011). The journey toward sustainability reporting: how accountable are the tourism industries? Tourism Recreation Research, 36(3), 247e257.

Honey, M. (2002). Ecotourism and certification: Setting standards in practice. Washington DC: Island Press.

Huybers, T., \& Bennett, J. (2003). Inter-firm cooperation at nature-based tourism destinations. Journal of Socio-economics, 32(5), 571-587. 
Ingram, C. (2007). Certification in protected areas: a Western Australian case study. In R. Black, \& A. Crabtree (Eds.), Quality assurance and certification in ecotourism (pp. 266-298). Wallingford: CAB International.

Inoue, Y., \& Lee, S. (2011). Effects of different dimensions of corporate social responsibility on corporate financial performance in tourism-related industries. Tourism Management, 32, $790 \mathrm{e} 804$.

Kassinis, G. I., \& Soteriou, A. C. (2003). Greening the service profit chain: the impact of environmental management practices. Production and Operations Management, 12, 386-402.

Khanna, M. (2001). Non-mandatory approaches to environmental protection. Journal of Economic Surveys, 15(3), 291-324.

Khanna, M., \& Kumar, S. (2011). Corporate environmental management and environmental efficiency. Environmental and Resource Economics, 50(2), 227-242.

Lee, J.-S., Hsu, L.-T.(J.), Han, H., \& Kim, Y. (2010). Understanding how consumers view green hotels: how a hotel's green image can influence behavioural intentions. Journal of Sustainable Tourism, 18, 901-914.

Lyon, T. P., \& Maxwell, J. W. (2008). Corporate social responsibility and the environment: a theoretical perspective. Review of Environmental Economics and Policy, 2(2), 240e260.

McCain, R. A. (2009). Game theory and public policy. Cheltenham: Edward Elgar.

McCain, R. A. (2010). Game theory: A nontechnical introduction to the analysis of strategy. Singapore: World Scientific Publishing Co.

McKenna, J., Williams, A. T., \& Cooper, J. A. G. (2011). Blue flag or red herring: do beach awards encourage the public to visit beaches? Tourism Management, 32(3), 576-588. 
Mair, J., \& Jago, L. (2010). The development of a conceptual model of greening in the business events tourism sector. Journal of Sustainable Tourism, 18(1), 77-94. http://dx.doi.org/10.1080/09669580903291007.

Mason, C. (2006). An economic model of ecolabeling. Environmental Modeling and Assessment, 11(2), 131-143.

Mason, P. (2007). No better than a band-aid for a bullet wound! The effectiveness of tourism codes of conduct. In R. Black, \& A. Crabtree (Eds.), Quality assurance and certification in ecotourism (pp. 46-64). Wallingford: CAB International.

Mason, C. (2011). Eco-labeling and market equilibria with noisy certification tests. Environmental and Resource Economics, 48(4), 537-560.

Mbaiwa, J. E., Magole, L. I., \& Kgathi, D. L. (2011). Prospects and challenges for tourism certification in Botswana. Tourism Recreation Research, 36(3), 259-270.

Miller, G., Rathouse, K., Scarles, C., Holmes, K., \& Tribe, J. (2010). Public understanding of sustainable tourism. Annals of Tourism Research, 37(3), 627-645.

http://dx.doi.org/10.1016/j.annals.2009.12.002.

Nicolau, J. L. (2008). Corporate social responsibility: worth-creating activities. Annals of Tourism Research, 35, 990-1006.

Nunez, J. (2007). Can self regulation work?: a story of corruption, impunity and cover-up. Journal of Regulatory Economics, 31, 209-233.

Ott, M., Choi, Y. J., Cardie, C., \& Hancock, J. T. (2011). Finding deceptive opinion spam by any stretch of the imagination. ACL Proceedings, 49, 309-319.

Ottman, J. A., Stafford, E. R., \& Hartman, C. L. (2006). Avoiding green marketing myopia: ways to improve consumer appeal for environmentally preferable products. Environment, 48 , 22-36. 
Parsons, C., \& Grant, J. (2007). Green globe: a global environmental certification programme for travel and tourism. In R. Black, \& A. Crabtree (Eds.), Quality assurance and certification in ecotourism (pp. 81-100).Wallingford: CAB International.

Reed, M. G. (1997). Power relations and community-based tourism planning. Annals of Tourism Research, 24(3), 566-591.

Rivera, J. (2002). Assessing a voluntary environmental initiative in the developing world: the Costa Rican certification for sustainable tourism. Policy Sciences, 35, 333-360.

Rowe, T., \& Higham, J. (2007). Ecotourism certification in New Zealand: operator and industry perspectives. In R. Black, \& A. Crabtree (Eds.), Quality assurance and certification in ecotourism (pp. 395-414). Wallingford: CAB International.

Sacconi, L. (2006). A social contract for CSR as an extended model of corporate governance (I): rational bargaining and justification. Journal of Business Ethics, 68(3), 259-281.

Sheldon, P. J., \& Park, S.-Y. (2011). An exploratory study of corporate social responsibility in the US travel industry. Journal of Travel Research, 50(4), 392-407.

Stabler, M., Papatheodorou, A., \& Sinclair, T. (2010). Game theory and tourism. The economics of tourism. s.4.4.

Tang, Z., Hu, Y. U., \& Smith, M. D. (2008). Gaining trust through online privacy protection: self-regulation, mandatory standards, or caveat emptor. Journal of Management Information Systems, 24(4), 153-173.

Thwaites, R. (2007). The Australian ecocertification programme (NEAP): blazing a trail for ecotourism certification, but keeping on track? In R. Black, \& A. Crabtree (Eds.), Quality assurance and certification in ecotourism (pp. 435-465) Wallingford: CAB International.

Treves, T., \& Jones, S. M. (2010). Strategic tradeoffs for wildlife-friendly eco-labels. Frontiers in Ecology and the Environment, 8, 491-498. 
Van't Veld, K., \& Kotchen, M. J. (2011). Green clubs. Journal of Environmental Economics and Management, 62, 309-322.

Wagner, M. (2011). Corporate performance implications of extended stakeholder management: new insights on mediation and moderation effects. Ecological Economics, 70, 942-950.

Watterton, B. (1996). It's a magical world. Kansas: Andrews McMeel.

Whiteman, G. (2011). Corporate greening falls short. Nature, 473, 149.

Whittaker, J. (2011). The evolution of environmentally responsible investment: an Adam Smith perspective. Ecological Economics, 71, 33-41.

Wie, B. W. (2005). A dynamic game model of strategic capacity investment in the cruise line industry. Tourism Management, 26, 203-217.

Yang, S., Huang, G. Q., Song, H., \& Liang, L. (2009). Game-theoretic approach to competition dynamics in tourism supply chains. Journal of Travel Research, 47, 425-439.

Zhong, L., Deng, J., Song, Z., \& Ding, P. (2011). Research on environmental impacts of tourism in China: progress and prospect. Journal of Environmental Management, 92(11), 2972-2983. http://dx.doi.org/10.1016/j.jenvman.2011.07.011. 
Ralf Buckley is Director of the International Centre for Ecotourism Research at Griffith University, Australia, currently ranked world first in sustainable tourism research. He has $\sim 750$ publications including 200 journal articles, and has published previously in Tourism Management on aspects of adventure tourism. 


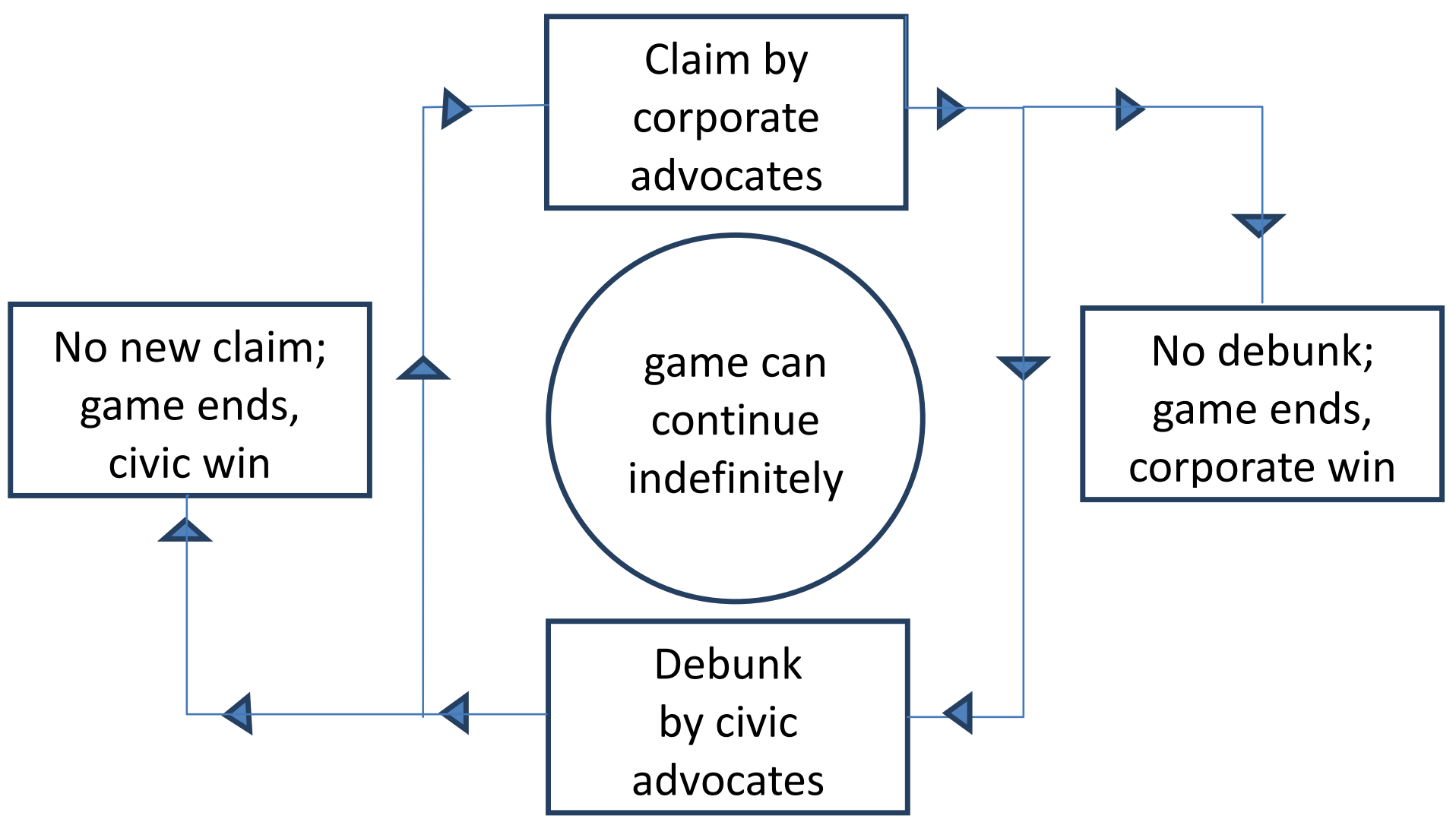


Table 1. Types and Beneficiaries of Tourism Ecocertification Programmes

\begin{tabular}{|c|c|c|c|c|c|}
\hline Subject & $\begin{array}{l}\text { Scale and } \\
\text { Location }\end{array}$ & Type & $\begin{array}{l}\text { Principal } \\
\text { Beneficiary }\end{array}$ & Benefit & Cases in \\
\hline $\begin{array}{l}\text { environmental } \\
\text { quality }\end{array}$ & $\begin{array}{l}\text { tourism } \\
\text { destinations }\end{array}$ & $\begin{array}{l}\text { consumer } \\
\text { benefit; } \\
\text { experience } \\
\text { goods }\end{array}$ & tourists & $\begin{array}{l}\text { choice of } \\
\text { destination }\end{array}$ & $\begin{array}{l}\text { Europe }^{a} \\
\text { China }^{b}\end{array}$ \\
\hline $\begin{array}{l}\text { environmental } \\
\text { interpretation }\end{array}$ & $\begin{array}{l}\text { nature } \\
\text { guides }\end{array}$ & $\begin{array}{l}\text { consumer } \\
\text { benefit; } \\
\text { experience } \\
\text { goods }\end{array}$ & tourists & $\begin{array}{l}\text { service } \\
\text { quality }\end{array}$ & $\begin{array}{l}\text { South Africa }{ }^{c} \\
\text { Australia }^{d}\end{array}$ \\
\hline $\begin{array}{l}\text { environmental } \\
\text { management } \\
\text { performance }\end{array}$ & $\begin{array}{l}\text { small-scale } \\
\text { mobile outdoor } \\
\text { tours in parks }\end{array}$ & $\begin{array}{l}\text { social } \\
\text { benefit; } \\
\text { experience } \\
\text { goods for } \\
\text { parks agency }\end{array}$ & $\begin{array}{l}\text { tour } \\
\text { operator }\end{array}$ & $\begin{array}{l}\text { preferential } \\
\text { permitting } \\
\text { from parks } \\
\text { agency }\end{array}$ & $\begin{array}{l}\text { New Zealand } \\
\text { Australia }^{\mathrm{f}}\end{array}$ \\
\hline $\begin{array}{l}\text { environmental } \\
\text { management } \\
\text { performance }\end{array}$ & $\begin{array}{l}\text { large-scale } \\
\text { mainstream } \\
\text { transport, } \\
\text { activities, } \\
\text { accommodation, } \\
\text { hospitality }\end{array}$ & $\begin{array}{l}\text { social } \\
\text { benefit; } \\
\text { credence } \\
\text { goods }\end{array}$ & tourists (?) & $\begin{array}{l}\text { individual } \\
\text { satisfaction } \\
\text { at social } \\
\text { contribution } \\
\text { expectation } \\
\text { of reduced } \\
\text { impact on } \\
\text { environment }\end{array}$ & $\begin{array}{l}\text { tourists } \\
\text { ignore or } \\
\text { unaware } \\
\text { worldwide, } \\
>100 \\
\text { programs }^{\mathrm{g}}\end{array}$ \\
\hline
\end{tabular}

Notes: ${ }^{a}$ McKenna, et al. (2011). ${ }^{b}$ Zhong, et al. (2011). ${ }^{c}$ Field Guides Association of Southern Africa (2012). ${ }^{\mathrm{d}}$ Black (2007). ${ }^{\mathrm{e}}$ Rowe \& Higham (2007). ${ }^{\mathrm{f}}$ GBRMPA (2012); Ingram (2007); Thwaites (2007). ${ }^{\mathrm{g}}$ Font \& Buckley (2001); Black \& Crabtree (2007). 
Table 2.

\begin{tabular}{|c|c|c|c|c|c|c|c|}
\hline $\begin{array}{l}\text { Spatial } \\
\text { scale }\end{array}$ & $\begin{array}{l}\text { Lead } \\
\text { agency }^{a}\end{array}$ & $\begin{array}{l}\text { Program } \\
\text { name }^{b}\end{array}$ & $\begin{array}{l}\text { Agency } \\
\text { role }\end{array}$ & $\begin{array}{l}\text { Industr } \\
\text { y sectors }\end{array}$ & $\begin{array}{l}\text { Approach } \\
\text { or scope }\end{array}$ & Status & Level $^{d}$ \\
\hline world & ISO & ISO 14001 & operate & $\begin{array}{l}\text { all, incl } \\
\text { tourism }\end{array}$ & EMS & operational & firms \\
\hline world & UN & GRI & oversight & all & $\begin{array}{l}\text { CSR report } \\
\text { standard }\end{array}$ & operational & firms \\
\hline world & UNWTO & TOIST & coordinate & tourism & guidelines & operational & firms \\
\hline world & GSTC & GSTC & operate & tourism & $\begin{array}{l}\text { voluntary } \\
\text { criteria }\end{array}$ & operational & $\begin{array}{l}\text { certification } \\
\text { programs }\end{array}$ \\
\hline world & WHL & WHL & operate & hotels & $\begin{array}{l}\text { customer } \\
\text { feedback }\end{array}$ & operational & hotels \\
\hline $\begin{array}{l}\text { continent } \\
\text { (USA) }\end{array}$ & GG USA & $\begin{array}{l}\text { Green } \\
\text { Globe }\end{array}$ & operate & hotels & $\begin{array}{l}\text { membership, } \\
\text { certify }\end{array}$ & operational & firms \\
\hline $\begin{array}{l}\text { continent } \\
\text { (Asia) }\end{array}$ & $\begin{array}{l}\text { Earth } \\
\text { Check }^{\mathrm{e}}\end{array}$ & $\begin{array}{l}\text { Earth } \\
\text { Check }^{\mathrm{e}}\end{array}$ & operate & tourism & $\begin{array}{l}\text { membership, } \\
\text { certify }\end{array}$ & operational & firms \\
\hline $\begin{array}{l}\text { continent } \\
\text { (Europe) }\end{array}$ & $\mathrm{EU}$ & EMAS & operate & $\begin{array}{l}\text { all, incl. } \\
\text { tourism }\end{array}$ & EMS & operational & firms \\
\hline $\begin{array}{l}\text { continent } \\
\text { (Europe) }\end{array}$ & $\mathrm{EU}$ & EETLS & seed funds & tourism & $\begin{array}{l}\text { template, } \\
\text { ?accredit }\end{array}$ & $\begin{array}{l}\text { criteria } \\
\text { finalised }\end{array}$ & $\begin{array}{l}\text { certification } \\
\text { programs }\end{array}$ \\
\hline $\begin{array}{l}\text { continent } \\
\text { (Europe) }\end{array}$ & & Travelife & operate & tourism & $\begin{array}{l}\text { membership, } \\
\text { certify }\end{array}$ & operational & firms \\
\hline $\begin{array}{l}\text { continent } \\
\text { (Caribb.) }\end{array}$ & CAST & CST & operate & ecotours & $\begin{array}{l}\text { membership, } \\
\text { certify }\end{array}$ & operational & products \\
\hline $\begin{array}{l}\text { continent } \\
\text { (Asia) }\end{array}$ & PATA & $\begin{array}{l}\text { Green } \\
\text { Leaf }\end{array}$ & operate & tourism & membership & ?revived & firms \\
\hline $\begin{array}{l}\text { continent } \\
\text { (Australia) }\end{array}$ & $\begin{array}{l}\text { Ecotour. } \\
\text { Australia }\end{array}$ & EA & operate & ecotours & $\begin{array}{l}\text { membership, } \\
\text { certify }\end{array}$ & operational & products \\
\hline $\begin{array}{l}\text { continent } \\
\text { (China) }\end{array}$ & CNTA & $\begin{array}{l}\text { Ecotour } \\
\text { Standard }\end{array}$ & operate & tourism & $\begin{array}{l}\text { membership, } \\
\text { competitive }\end{array}$ & operational & $\begin{array}{l}\text { products, } \\
\text { destinations }\end{array}$ \\
\hline $\begin{array}{l}\text { sub-cont } \\
\text { (Scand.) }\end{array}$ & & Nordic & operate & hotels & $\begin{array}{l}\text { membership, } \\
\text { certify }\end{array}$ & operational & hotels \\
\hline sub-cont & & ECEAT & operate & tourism & membership & operational & $\begin{array}{l}\text { national } \\
\text { programs }\end{array}$ \\
\hline sub-cont & & Ecotrans & operate & tourism & membership & operational & firms \\
\hline
\end{tabular}


Notes.

${ }^{a}$ ISO, International Standards Organisation; UNWTO, United Nations Tourism Organisation; GSTC, Global Sustainable Tourism Council; WHL, World Hotel-Link (NB: seed funds from World Bank); GG, Green Globe (USA); CAST, Caribbean Alliance for Sustainable Tourism; PATA, Pacific-Asia Travel Association; CNTA, Chinese National Tourism Administration. bGRI, Global Reporting Initiative; TOIST, Tour Operators' Initiative for Sustainable Tourism; GSTC, Global Sustainable Tourism Criteria; EMAS, Environmental Management and Audit System; EETLS, European Ecotourism Labelling Standard. 'EMS, Environmental Management System. Membership systems generally offer certification but this may be weak. ${ }^{\mathrm{d}}$ Principal level, may also include other levels. ${ }^{\mathrm{e}}$ Previously Green Globe Asia-Pacific. 
Figure 1a: Historical Evolution of Tourism Ecocertification

\begin{tabular}{|c|c|c|}
\hline Corporate Advocates & $\begin{array}{l}\text { [Consumer } \\
\text { responses] }\end{array}$ & Civic Advocates \\
\hline $\begin{array}{l}\text { Claim tourism has negligible } \\
\text { environmental impacts }\end{array}$ & & $\begin{array}{l}\text { Demonstrate impacts, } \\
\text { argue for environmental } \\
\text { regulations }\end{array}$ \\
\hline $\begin{array}{l}\text { Promote environmental } \\
\text { management guidelines } \\
\text { instead of regulation }\end{array}$ & & $\begin{array}{l}\text { Show guidelines are not } \\
\text { followed; promote } \\
\text { ecotourism (see Fig 1b) }\end{array}$ \\
\hline $\begin{array}{l}\text { Promote certification as a } \\
\text { mechanism for concerned } \\
\text { customer choice } \\
\text { [subgame as certification } \\
\text { schemes compete for } \\
\text { dominance] }\end{array}$ & $\begin{array}{l}\text { [most tourists } \\
\text { ignore } \\
\text { ecocertificates] }\end{array}$ & $\begin{array}{l}\text { Show ecocertification } \\
\text { programs are weak, } \\
\text { demand a global } \\
\text { accreditation authority to } \\
\text { identify which are } \\
\text { effective }\end{array}$ \\
\hline $\begin{array}{l}\text { Argue for a consultative } \\
\text { mechanism and certification } \\
\text { criteria rather than an } \\
\text { accreditation authority }\end{array}$ & & $\begin{array}{l}\text { (a) Contribute to criteria, } \\
\text { and (b) establish NGO } \\
\text { environmental awards as } \\
\text { stronger alternative }\end{array}$ \\
\hline $\begin{array}{l}\text { Set up industry eco-awards in } \\
\text { competition, causing } \\
\text { confusion }\end{array}$ & $\begin{array}{l}\text { [most tourists } \\
\text { ignore eco- } \\
\text { awards] }\end{array}$ & $\begin{array}{l}\text { Criticise industry awards } \\
\text { for diluting environmental } \\
\text { performance with social } \\
\text { and service quality issues }\end{array}$ \\
\hline $\begin{array}{l}\text { Advertise industry awards } \\
\text { heavily, swamp NGO awards }\end{array}$ & & $\begin{array}{l}\text { [no response: insufficient } \\
\text { funds] } * * *\end{array}$ \\
\hline $\begin{array}{l}\text { Establish Global Sustainable } \\
\text { Tourism Criteria (see Table 1) }\end{array}$ & & Criticise GSTC as weak \\
\hline \multirow[t]{2}{*}{$\begin{array}{l}\text { Claim environment advocates } \\
\text { contributed to GSTC }\end{array}$} & & $\begin{array}{l}\text { [no response: co-opted] } \\
* * *\end{array}$ \\
\hline & & $\begin{array}{l}\text { New policy concerns over } \\
\text { climate change, carbon } \\
\text { footprints }\end{array}$ \\
\hline $\begin{array}{l}\text { Sell carbon offsets as } \\
\text { mechanism for consumer } \\
\text { choice; promote climate } \\
\text { certification, copying previous } \\
\text { ecocertification strategy }\end{array}$ & $\begin{array}{l}\text { [most tourists } \\
\text { ignore offset } \\
\text { programmes] }\end{array}$ & $\begin{array}{l}\text { Argue that offsets are } \\
\text { ineffective in practice; } \\
\text { unable to oppose them on } \\
\text { principle, since supported } \\
\text { them elsewhere. } * * *\end{array}$ \\
\hline
\end{tabular}


Figure 1b: Ecotourism Side Game

\begin{tabular}{|l|l|}
\hline $\begin{array}{l}\text { Corporate } \\
\text { Advocates }\end{array}$ & $\begin{array}{l}\text { Civic } \\
\text { Advocates }\end{array}$ \\
\hline & $\begin{array}{l}\text { Distinguish niche-market 'ecotourism' } \\
\text { from 'mainstream' or 'mass' tourism }\end{array}$ \\
\hline $\begin{array}{l}\text { Widespread claims of ecotourism, } \\
\text { but using undefined criteria }\end{array}$ & $\begin{array}{l}\text { Call these 'ecotourism lite' or greenwash, } \\
\text { demand certification }\end{array}$ \\
\hline $\begin{array}{l}\text { Establish ecotourism certification } \\
\text { programs, but with very lax criteria }\end{array}$ & $\begin{array}{l}\text { Criticise these, demand accreditation of } \\
\text { ecotourism certification programs }\end{array}$ \\
\hline
\end{tabular}


Figure 2b. Outcome matrix from Figure 2a.

\begin{tabular}{|l|l|l|}
\hline & $\begin{array}{l}\text { Corporate advocates } \\
\text { claim better EMP }\end{array}$ & $\begin{array}{l}\text { Corporate advocates } \\
\text { make no claim }\end{array}$ \\
\hline $\begin{array}{l}\text { Civic advocates debunk } \\
\text { claims of better EMP }\end{array}$ & Keep playing & $\begin{array}{l}\text { Civic advocates win; } \\
\text { game ends }\end{array}$ \\
\hline $\begin{array}{l}\text { Civic advocates make no } \\
\text { claim or fail to debunk }\end{array}$ & $\begin{array}{l}\text { Corporate advocates win; } \\
\text { game ends }\end{array}$ & \\
\hline
\end{tabular}


Figure 3a. Payoff matrix

\begin{tabular}{|c|c|c|c|}
\hline & & \multicolumn{2}{|c|}{ Payoff for corporate advocates } \\
\hline & & Keep playing & Stop playing \\
\hline \multirow{2}{*}{$\begin{array}{l}\text { Payoff for } \\
\text { civic } \\
\text { advocates }\end{array}$} & Keep playing & $\begin{array}{l}\text { Alternating move and } \\
\text { countermove; small } \\
\text { continuing cost; maintain } \\
\text { chance of winning }\end{array}$ & $\begin{array}{l}\text { Civil advocates achieve stronger } \\
\text { environmental regulation; } \\
\text { corporate advocates perceive this } \\
\text { as a loss }\end{array}$ \\
\hline & Stop playing & $\begin{array}{l}\text { Corporate advocates achieve } \\
\text { weaker regulation; civil } \\
\text { advocates perceive this as a } \\
\text { loss }\end{array}$ & $\begin{array}{l}\text { Both advocates save the cost of } \\
\text { playing, but if either re-enters the } \\
\text { game, the other loses; so for each } \\
\text { player independently, the expected } \\
\text { outcome is the same as a unilateral } \\
\text { stop play }\end{array}$ \\
\hline
\end{tabular}

Figure 3b. Numerical payoff matrix

Payoff for corporate advocates

\begin{tabular}{|l|l|l|l|}
\hline \multicolumn{2}{|c|}{} & Play & Stop \\
\hline \multirow{2}{*}{$\begin{array}{l}\text { Payoff for civic } \\
\text { advocates }\end{array}$} & Play & $-(<<1)$ & -1 \\
\cline { 2 - 5 } & Stop & -1 & -1 \\
\hline
\end{tabular}


Table 3. Predictions from market and political-game frameworks

Test Market framework Political game

Will different countries adopt Yes. the same programs?

Will transparency and accountability improve?

Will certification schemes trend to equal sizes?
Single scheme gives greatest consumer recognition.

Yes.

Consumers want reliable info
No.

National DMOs in competition

No.

Corporate advocates gain from confusion.

Yes.

Ecofake schemes will continue to arise. Larger ones more likely to be uncovered. 